\title{
Prognosis of coal-miners with cancer of the lung
}

\author{
K. P. GOLDMAN \\ From Sully Hospital, Sully, Glamorgan ${ }^{1}$
}

It has been suggested that the prognosis of coalminers who develop lung cancer differs from that of non-miners. This idea was first proposed by Smith (1959), who reported that the results of surgical treatment were especially favourable among miners. His review of 320 surgical resections for lung cancer showed that the two years' survival rate was $86 \%$ for 21 coal-miners compared with only $36 \%$ for the whole series. However, the number of miners was small and the period of follow-up relatively short, so that this evidence cannot be regarded as conclusive.

Gernez-Rieux, Voisin, Balgairies, Delepoulle, and Lenoir (1961) investigated a series of 59 French coal-miners with lung cancer, 39 of whom had radiographic evidence of pneumoconiosis. Only six of the miners were treated surgically (four refused operation), of whom all except one were dead within 12 months of operation. The authors emphasized the special difficulties of clinical and radiographic diagnosis and concluded that miners with lung cancer have a relatively poor prognosis which results largely from delays in diagnosis.

The conflict of opinion expressed in these two papers provided the stimulus for a more extensive investigation into the comparative survival experience of miners and non-miners with lung cancer. The intention was also to determine whether the prognosis is influenced by coincidental pneumoconiosis.

\section{MATERIAL AND METHODS}

A retrospective survey was conducted on all the patients who attended Sully Hospital during the period 1 January 1954 to 1 October 1960 and who were thought to have primary carcinoma of the lung. This hospital is the regional thoracic centre for South Wales, and the population it serves includes the miners of the South Wales coalfield. Information was obtained from the case notes and chest radiographs of 746 in-patients and outpatients, of whom 690 were males. Patients in whom, in retrospect, the diagnosis seemed un-

\footnotetext{
1 Present address : Brompton Hospital, London, S.W.3
}

certain were excluded. The material was analysed according to age, respiratory function, tumour histology, method of treatment, and survival.

The males were subdivided according to occupation; men who at any time in their lives had worked in a coal-mine for five years or longer were classed as miners, whereas all other men were classed as non-miners. There were 172 miners and 518 non-miners, a ratio of $1: 3$. There was little difference in the age structure of the two groups (Table I), the average age being 57.9 years for miners and 58.6 years for non-miners.

T A B L E I

AGES OF MINERS AND NON-MINERS WITH CARCINOMA OF THE LUNG

\begin{tabular}{|c|c|c|c|c|c|}
\hline \multirow{2}{*}{\multicolumn{2}{|c|}{$\begin{array}{c}\text { Age } \\
\text { (years) }\end{array}$}} & \multicolumn{2}{|c|}{ Non-miners } & \multicolumn{2}{|c|}{ Miners } \\
\hline & & No. & $\%$ & No. & $\%$ \\
\hline $\begin{array}{l}\text { Under } 40 \\
40-49 \ldots \\
50-59 \ldots \\
60-69 \ldots \\
70 \text { and over }\end{array}$ & $\begin{array}{l}\ldots \\
\ldots \\
\ldots \\
\cdots\end{array}$ & $\begin{array}{r}6 \\
42 \\
226 \\
211 \\
33\end{array}$ & $\begin{array}{r}1 \cdot 1 \\
8 \cdot 1 \\
43 \cdot 8 \\
40 \cdot 6 \\
6 \cdot 3\end{array}$ & $\begin{array}{r}2 \\
20 \\
72 \\
69 \\
9\end{array}$ & $\begin{array}{r}1.2 \\
11.6 \\
41.9 \\
40 \cdot 1 \\
5.3\end{array}$ \\
\hline All ages & $\ldots$ & 518 & $100 \cdot 0$ & 172 & $100 \cdot 0$ \\
\hline
\end{tabular}

The miners' chest radiographs taken at the time of diagnosis were assessed for simple pneumoconiosis by an independent observer (Professor A. L. Cochrane) who received no information except that lung cancer had been diagnosed. The radiographic categories of pneumoconiosis used were those of the latest international classification (International Labour Office, 1959), and in addition category $\frac{1}{2}$ was introduced; this was defined as showing radiographic evidence of simple pneumoconiosis but less than category 1 . The chest radiographs were also assessed by the author for progressive massive fibrosis. Simple pneumoconiosis was reported in $42 \%$ of the miners, in most cases category 1 or less, and among these there were only five with progressive massive fibrosis (Table II). There was a slight age gradient with the rise in category of pneumoconiosis, the average age of miners in categories 2 and 3 being 59.2 years compared with 57.6 for all other miners. 
TABLE II

INCIDENCE OF PNEUMOCONIOSIS IN 172 COAL-MINERS WITH LUNG CANCER

\begin{tabular}{c|c}
\hline Radiographic Category & Number of Miners \\
\hline 0 & 100 \\
$\frac{1}{2}$ & 23 \\
1 & 30 \\
2 & 14 \\
3 & 5 \\
[P.M.F. & $5]$ \\
\hline
\end{tabular}

The ventilatory capacity had been recorded for 503 men, of whom 135 were miners and 368 nonminers. This was assessed by spirometric measurement of the volume of air expelled in the first 0.75 second of forced expiration (McKerrow, McDermott, and Gilson, 1960). This test showed the miners to be at a slight disadvantage since their mean F.E.V..$_{0.75}$ was 1.48 litres compared with 1.63 litres for non-miners. The F.E.V. was below 1.201 . in $30.4 \%$, between 1.20 and 1.601 . in $34.8 \%$, and above 1.601 . in $34.8 \%$ of miners, compared with $26 \cdot 1 \%, 27 \cdot 7 \%$, and $46 \cdot 2 \%$ respectively for non-miners. Of the miners who were tested, the mean F.E.V. of those with radiographic evidence of pneumoconiosis $(1.531$.) was slightly higher than that of those without (1.45 1.).

The diagnosis of lung cancer was supported by the pathologist's report on histology or cytology in 601 cases, or $81 \%$ of the total. Classification where possible was according to the predominant cell type into squamous cell, adenocarcinoma, oat cell, and undifferentiated carcinoma. The frequency of these histological types differed in the two occupational groups, for there was a higher proportion of squamous cell and oat cell tumours among the miners and a higher proportion of undifferentiated tumours among the non-miners (Table III).
The survival of patients was measured from the day of operation or, for those not treated surgically, from the date of diagnosis to 1 October 1962. Deaths from lung cancer were not distinguished from deaths from other causes. Information was obtained from hospital records, general practitioners, chest clinics, local health executive councils, and the Registrar General, and all 746 patients were traced.

TABLE III

HISTOLOGICAL TYPE OF TUMOUR IN MINERS AND NON-MINERS

\begin{tabular}{|c|c|c|c|c|c|}
\hline \multirow{2}{*}{\multicolumn{2}{|c|}{ Cell Type }} & \multicolumn{2}{|c|}{ Non-miners } & \multicolumn{2}{|c|}{ Miners } \\
\hline & & No. & $\%$ & No. & $\%$ \\
\hline $\begin{array}{l}\text { Squamous . . } \\
\text { Undifferentiated } \\
\text { Oat cell .. } \\
\text { Adenocarcinoma } \\
\text { Unclassified ... }\end{array}$ & $\begin{array}{l}\cdots \\
\cdots \\
\cdots \\
\cdots\end{array}$ & $\begin{array}{r}162 \\
146 \\
78 \\
27 \\
19\end{array}$ & $\begin{array}{r}37 \cdot 5 \\
33 \cdot 8 \\
18 \cdot 1 \\
6 \cdot 2 \\
4 \cdot 4\end{array}$ & $\begin{array}{r}57 \\
17 \\
34 \\
11 \\
6\end{array}$ & $\begin{array}{r}45 \cdot 6 \\
13 \cdot 6 \\
27 \cdot 2 \\
8 \cdot 8 \\
4 \cdot 8\end{array}$ \\
\hline All types & $\ldots$ & 432 & $100 \cdot 0$ & 125 & $100 \cdot 0$ \\
\hline
\end{tabular}

\section{RESULTS}

The survival rates of miners and non-miners have been recorded according to surgical treatment or otherwise. A similar proportion was treated by pulmonary resection in each group, namely $32 \%$ of miners and $35.5 \%$ of non-miners. Their survival has been expressed in the form of life-tables into which the experience of those who were followed for periods varying between two and five years from the time of operation has been incorporated. These tables are valid only if the death rate remained constant throughout the period covered, and as the operative mortality in this series varied according to the year of operation these deaths have been excluded and analysed separately.

TABLE IV】

EXPECTATION OF LIFE IN MINERS AND NON-MINERS WHO SURVIVED SURGICAL RESECTION BY AT LEAST FOUR WEEKS

\begin{tabular}{|c|c|c|c|c|c|c|c|c|c|c|}
\hline \multirow{2}{*}{\multicolumn{4}{|c|}{ Period after Resection }} & \multirow{2}{*}{$\begin{array}{c}\text { At Risk } \\
\text { during This } \\
\text { Period }\end{array}$} & \multicolumn{2}{|c|}{ Alive at End of } & \multirow{2}{*}{$\begin{array}{l}\text { Deaths in } \\
\text { This Period }\end{array}$} & \multirow{2}{*}{$\begin{array}{l}\text { Average Alive } \\
\text { at Mid-period }\end{array}$} & \multirow{2}{*}{$\begin{array}{c}\text { Probability of } \\
\text { Death in } \\
\text { This Period } \\
(\%)\end{array}$} & \multirow{2}{*}{$\begin{array}{c}\text { Survival Rate } \\
(\%)\end{array}$} \\
\hline & & & & & $\begin{array}{c}\text { Previous } \\
\text { Period }\end{array}$ & $\begin{array}{l}\text { Current } \\
\text { Period }\end{array}$ & & & & \\
\hline $\begin{array}{c}\text { Coal-miners: } \\
6 \text { months } \\
1 \text { year } \\
2 \text { years } \\
3 \text { years } \\
4 \text { years } \\
5 \text { years }\end{array}$ & $\begin{array}{l}\ldots \\
\cdots \\
\cdots \\
\cdots \\
\cdots\end{array}$ & $\begin{array}{l}\cdots \\
\cdots \\
\cdots \\
\cdots\end{array}$ & $\begin{array}{l}\cdots \\
\cdots \\
\cdots \\
\cdots \\
\cdots\end{array}$ & $\begin{array}{l}46 \\
46 \\
46 \\
33 \\
28 \\
20\end{array}$ & $\begin{array}{r}46 \\
40 \\
29 \\
16 \\
8 \\
4\end{array}$ & $\begin{array}{r}40 \\
29 \\
21 \\
11 \\
7 \\
3\end{array}$ & $\begin{array}{r}6 \\
11 \\
8 \\
5 \\
1 \\
1\end{array}$ & $\begin{array}{r}43 \cdot 0 \\
34 \cdot 5 \\
25 \cdot 0 \\
13 \cdot 5 \\
7 \cdot 5 \\
3 \cdot 5\end{array}$ & $\begin{array}{l}13.95 \\
31.88 \\
32.00 \\
37.04 \\
13.33 \\
28.57\end{array}$ & $\begin{array}{l}86 \cdot 05 \\
58 \cdot 62 \\
39 \cdot 86 \\
25 \cdot 10 \\
21 \cdot 75 \\
15 \cdot 54\end{array}$ \\
\hline $\begin{array}{c}\text { Non-miners: } \\
6 \text { months } \\
1 \text { year } \\
2 \text { years } \\
3 \text { years } \\
4 \text { years } \\
5 \text { years }\end{array}$ & $\begin{array}{l}\ldots \\
\cdots \\
\cdots \\
\cdots\end{array}$ & $\begin{array}{l}\ldots \\
\cdots \\
\cdots \\
\cdots\end{array}$ & $\begin{array}{l}\cdots \\
\cdots \\
\cdots \\
\cdots\end{array}$ & $\begin{array}{r}165 \\
165 \\
165 \\
132 \\
94 \\
78\end{array}$ & $\begin{array}{r}165 \\
131 \\
97 \\
53 \\
29 \\
24\end{array}$ & $\begin{array}{r}131 \\
97 \\
72 \\
42 \\
26 \\
19\end{array}$ & $\begin{array}{r}34 \\
34 \\
25 \\
11 \\
3 \\
5\end{array}$ & $\begin{array}{r}148 \cdot 0 \\
114 \cdot 0 \\
84 \cdot 5 \\
47 \cdot 5 \\
27 \cdot 5 \\
21 \cdot 5\end{array}$ & $\begin{array}{l}22.97 \\
29 \cdot 82 \\
29 \cdot 59 \\
23 \cdot 16 \\
10.91 \\
23.26\end{array}$ & $\begin{array}{l}77.03 \\
54.06 \\
38.06 \\
29.25 \\
26.06 \\
20.00\end{array}$ \\
\hline
\end{tabular}


The results show that there was little difference between the experience of miners and non-miners who survived operation by four weeks or more (Table IV). Expectation of survival six months after operation was greater for miners $(86 \%)$ than for non-miners $(77 \%)$, whereas the survival rate five years after operation was higher for nonminers $(20 \%)$ than for miners $(15.5 \%)$. However, these small differences are not statistically significant at the 5\% level (see Appendix, p. 174).

Operative mortality, defined as death within four weeks of operation, was greater for miners $(19 \cdot 4 \%)$ than for non-miners $(10.3 \%)$. This difference may have been related to the miners' inferior respiratory function, for in the series as a whole a rise in operative mortality was associated with a fall in ventilatory capacity (Table V).

T A B LE V

OPERATIVE MORTALITY RELATED TO VENTILATORY $\frac{\text { CAPACITY AND TO MINING CATEGORY }}{\text { Deaths within Four }}$

\begin{tabular}{|c|c|c|c|c|}
\hline & & No. of & $\begin{array}{l}\text { Death } \\
\text { Weeks }\end{array}$ & $\begin{array}{l}\text { n Four } \\
\text { eration }\end{array}$ \\
\hline & & & No. & $\%$ \\
\hline All patients $\ldots$ & . & 250 & 30 & $12 \cdot 0$ \\
\hline $\begin{array}{l}\text { I.M.B.C. } \\
651 \text {./min. or over } \\
641 \text {./min. or less }\end{array}$ & : & $\begin{array}{r}133 \\
87\end{array}$ & $\begin{array}{l}10 \\
13\end{array}$ & $\begin{array}{r}7 \cdot 5 \\
14 \cdot 9\end{array}$ \\
\hline $\begin{array}{lll}\text { Non-miners } & \ldots \\
\text { Miners } & \ldots & \end{array}$ & $\begin{array}{l}. \\
\text {. }\end{array}$ & $\begin{array}{r}184 \\
55\end{array}$ & $\begin{array}{r}19 \\
9\end{array}$ & $\begin{array}{l}10 \cdot 3 \\
16 \cdot 4\end{array}$ \\
\hline
\end{tabular}

${ }^{1}$ Not recorded in 30 patients, of whom seven died post-operatively

Little difference was shown between miners and non-miners with inoperable tumours, the two years' survival rate in each group being less than $2 \%$. These patients include those subjected to exploratory thoracotomy and found to be unresectable, patients who received radiotherapy or cytotoxic drugs, and the remainder who received no specific treatment. The comparative mortality of surgical and non-surgical patients is summarized in Table VI.

T A B L E V I

SURVIVAL RATES ACCORDING TO MINING CATEGORY

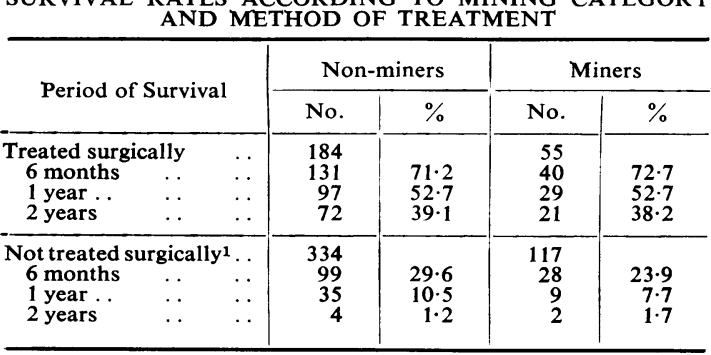

${ }^{1}$ From time of diagnosis
TABLE VII

SURVIVAL DURING FIRST TWO YEARS AFTER DIAGNOSIS (INOPERABLE CASES) OR TREATMENT (SURGICAL CASES) RELATED TO MINING CATEGORY

\begin{tabular}{|c|c|c|c|c|c|c|c|}
\hline \multirow{3}{*}{$\begin{array}{l}\text { Mining } \\
\text { Category }\end{array}$} & \multirow{3}{*}{$\begin{array}{l}\text { Total } \\
\text { No. }\end{array}$} & \multicolumn{6}{|c|}{ Survivors } \\
\hline & & \multicolumn{2}{|c|}{6 months } & \multicolumn{2}{|c|}{1 year } & \multicolumn{2}{|c|}{2 years } \\
\hline & & No. & $\%$ & No. & $\%$ & No. & $\%$ \\
\hline Non-miners & 518 & 230 & $44 \cdot 4$ & 132 & $25 \cdot 5$ & 76 & $14 \cdot 7$ \\
\hline $\begin{array}{c}\text { Miners } \\
0 \\
\frac{1}{2} \\
1 \\
2 \\
3\end{array}$ & $\begin{array}{r}100 \\
23 \\
30 \\
14 \\
5\end{array}$ & $\begin{array}{r}34 \\
10 \\
14 \\
7 \\
3\end{array}$ & $\begin{array}{l}34 \cdot 0 \\
43 \cdot 5 \\
46 \cdot 7 \\
50 \cdot 0 \\
60 \cdot 0\end{array}$ & $\begin{array}{r}16 \\
5 \\
9 \\
5 \\
2\end{array}$ & $\begin{array}{l}16.0 \\
21.7 \\
30.0 \\
35.7 \\
40.0\end{array}$ & $\begin{array}{l}9 \\
3 \\
5 \\
3 \\
2\end{array}$ & $\begin{array}{r}9 \cdot 0 \\
13 \cdot 0 \\
16 \cdot 7 \\
21 \cdot 4 \\
40 \cdot 0\end{array}$ \\
\hline
\end{tabular}

An analysis of the survival rates of the miners with lung cancer according to radiographic evidence of pneumoconiosis shows a trend towards an improved prognosis with a rise in category of simple pneumoconiosis (Table VII and Figure), a

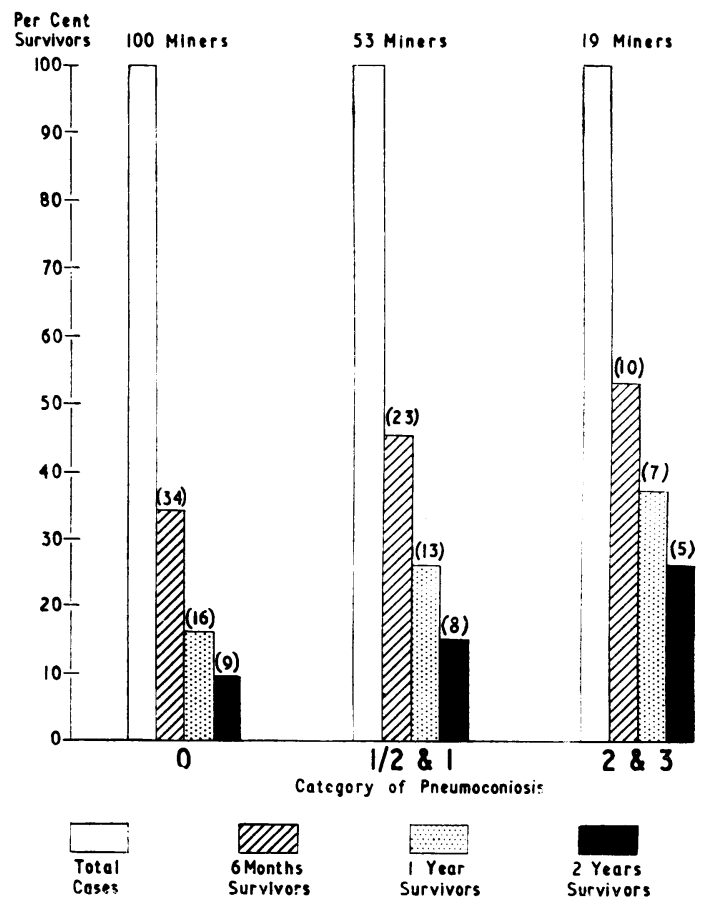

FIGURE Survival rates of 172 coal-miners with lung cancer related to radiographic category of simple pneumoconiosis.

trend which is evident for both surgical and nonsurgical cases (Table VIII). Thus the two years' survival rate of miners with categories 2 and 3 pneumoconiosis was $26 \%$, compared with $15 \%$ for categories 1 and $\frac{1}{2}$ and $9 \%$ for category 0 . The number of miners with the higher categories of 
TABLE VIII

SURVIVAL OF MINERS ACCORDING TO CATEGORY OF PNEUMOCONIOSIS AND METHOD OF TREATMENT

\begin{tabular}{|c|c|c|c|c|c|c|c|}
\hline \multirow{3}{*}{$\begin{array}{l}\text { Category } \\
\text { of } \\
\text { Pneumo- } \\
\text { coniosis }\end{array}$} & \multirow{3}{*}{$\begin{array}{l}\text { No. } \\
\text { at } \\
\text { Risk }\end{array}$} & \multicolumn{6}{|c|}{ Survivors } \\
\hline & & \multicolumn{2}{|c|}{6 months } & \multicolumn{2}{|c|}{1 year } & \multicolumn{2}{|c|}{2 years } \\
\hline & & No. & $\%$ & No. & $\%$ & No. & $\%$ \\
\hline $\begin{array}{c}\text { Treated } \\
\text { surgically } \\
0 \\
\frac{1}{2}+1 \\
2+3\end{array}$ & $\begin{array}{r}29 \\
21 \\
5\end{array}$ & $\begin{array}{r}21 \\
14 \\
5\end{array}$ & $\begin{array}{r}72.4 \\
66.7 \\
100.0\end{array}$ & $\begin{array}{r}14 \\
11 \\
5\end{array}$ & $\begin{array}{r}48 \cdot 3 \\
52.4 \\
100.0\end{array}$ & $\begin{array}{l}8 \\
8 \\
4\end{array}$ & $\begin{array}{l}27 \cdot 6 \\
38 \cdot 1 \\
80 \cdot 0\end{array}$ \\
\hline $\begin{array}{c}\text { Not treated } \\
\text { surgically } \\
0 \\
\frac{1}{2}+1 \\
2+3\end{array}$ & $\begin{array}{l}71 \\
32 \\
14\end{array}$ & $\begin{array}{r}14 \\
10 \\
5\end{array}$ & $\begin{array}{l}19.9 \\
31.2 \\
35.7\end{array}$ & $\begin{array}{l}4 \\
3 \\
2\end{array}$ & $\begin{array}{r}5 \cdot 6 \\
9.4 \\
14 \cdot 3\end{array}$ & $\begin{array}{l}1 \\
0 \\
1\end{array}$ & $\begin{array}{l}1.4 \\
0.0 \\
7 \cdot 1\end{array}$ \\
\hline
\end{tabular}

pneumoconiosis was small, which limits the statistical significance of the results, but the consistency throughout the series with which survival is related to the category of pneumoconiosis renders it unlikely that the trend is the effect of chance.

\section{DISCUSSION}

Does the occupation of coal-mining have any influence on the survival of men who develop cancer of the lung? The evidence from this retrospective survey of a large hospital series suggests that the survival rates of miners and non-miners with lung cancer are similar whether they are treated surgically or otherwise. This finding differs from that of other workers previously quoted, for Smith recorded a specially high survival rate in miners who had been treated surgically, whereas Gernez-Rieux and his colleagues reported a particularly poor prognosis for these men. The discrepancy probably results from the relatively small samples of miners studied by these authors, whose data are liable to misinterpretation in the absence of comparative data on control groups of non-miners.

Among the miners with lung cancer in the present series the prognosis improved with a rise in the radiographic category of simple pneumoconiosis. Thus survival rates were lowest for miners in category 0 (lower than for non-miners), intermediate for those in categories $\frac{1}{2}$ and 1 (similar to those of non-miners), and highest for the small proportion of miners in categories 2 and 3.

It is possible that the favourable rates in the last group were caused by an associated factor of prognostic importance other than pneumoconiosis. For example, among miners in categories 2 and 3 there was a relatively high proportion of squamous cell tumours $(53.3 \%)$ and a relatively low propor- tion of oat cell tumours $(20 \%)$, a distribution which might be expected to confer a prognostic advantage. Yet this is not reflected in the rate of surgical resection, which was only $26.3 \%$, or below the rate for other miners $(32.7 \%)$.

On the evidence available it is thought that in miners with lung cancer the association between improved prognosis and a rise in category of coincidental pneumoconiosis is likely to be causal; in which case the question arises how the progress of a tumour might be modified by the presence of coal-dust in the lungs.

It is generally accepted that an important mode of cancer dissemination is by the passage of lymphatic tumour emboli, and there is experimental evidence that the passage of such emboli is delayed at lymph nodes. Thus when cancer cells are injected into the efferent lymphatic vessels of popliteal nodes in rabbits, passage of the cells through the nodes is delayed for about six weeks, by which time the nodes have been destroyed by growth (Zeidman and Buss, 1954). Filtration of tumour emboli at lymph nodes has also been postulated by Gilchrist (1940) and by Willis (1952) from studies of the human pathology of cancer of the rectum and lung respectively. In coal-miners' lungs, much inhaled dust is taken into the lymphatics by phagocytes and deposited in the regional lymph nodes. These anthracotic nodes are typically hard and black, and the afferent lymphatics are engorged with coal-laden macrophages suggesting an obstruction to lymph flow (Heppleston, 1947). It seems likely that the passage of tumour cells along these lymph vessels and through the nodes will be impeded by the dust, thereby delaying the escape of cancer to other organs of the body.

Supposing there is such a favourable effect, it would probably be of limited duration, for in time the cancer would reach the lymph nodes by progressive growth along the lymphatics, and then destruction of the node would remove its filtration effect. Yet in a proportion of miners this delay in cancer dissemination could be important and influence the results of surgical treatment, as suggested by Smith (1959). On the other hand, pneumoconiosis can have little influence on tumour dissemination via the blood vessels, which is thought by some workers to occur earlier than lymphatic dissemination (Pryce and Walter, 1960) and to exert a greater effect on prognosis (Collier, Blakemore, Kyle, Enterline, Kirby, and Johnson, 1957).

On theoretical grounds it remains uncertain whether lymphatic blockade by coal-dust would impede the spread of lung cancer sufficiently to 
influence survival, although the finding of a relatively favourable prognosis among miners with categories 2 and 3 pneumoconiosis might be considered as evidence in support of this effect. However, the miners in these categories formed only a small proportion of the total, and this series is drawn from an area where the prevalence of pneumoconiosis is particularly high. Among miners with lung cancer from areas other than South Wales, relatively fewer are likely to have pneumoconiosis of sufficient extent for it to influence the prognosis favourably.

\section{SUMMARY}

The results are presented of an investigation into the comparative survival experience of coalminers and non-miners with cancer of the lung. A retrospective survey was conducted on 746 hospital patients from South Wales, of whom 172 had been miners and 518 non-miners. During the first five years of follow-up there was no appreciable difference in survival rates between the two occupational groups, whether they were treated surgically or otherwise, and the rate of surgical resection was similar in each group.

However, an analysis of the miners' experience in relation to the presence and extent of coincidental pneumoconiosis showed a consistent association, survival increasing with a rise in the radiographic category of simple pneumoconiosis. The highest two-years survival rates in the series were in the small proportion of miners with categories 2 and 3 pneumoconiosis. This association would be expected if the spread of lung sancer in miners' lungs were impeded by coal-dust.

I am most grateful to Professor A. L. Cochrane. Director of the Epidemiological Research Unit, Medical Research Council, South Wales, for his classification of the miners' chest radiographs according to category of simple pneumoconiosis; to Dr. L. R. West for his encouragement and help ; to Mr. C. E. Rossiter and Dr. R. A. M. Case for assistance with statistics; and to Dr. H. M. Foreman, Physician Superintendent, for permission to report on clinical material from Sully Hospital. My thanks are due to Miss G. Smith for help with the tracing of patients and to Miss G. Sweet for secretarial assistance. The material for this study formed part of a thesis submitted to the University of Cambridge for the M.D. degree.

\section{REFERENCES}

Collier, F. C., Blakemore, W. S., Kyle, R. H., Enterline, H. T., Kirby, C. K., and Johnson, J. (1957). Carcinoma of the lung: factors which influence five-year survival, with special reference to blood vessel invasion. Ann. Surg., 146, 417.

Gernez-Rieux, Ch., Voisin, C., Balgairies, E., Delepoulle, E., and Lenoir, L. (1961). Le cancer primitif du poumon chez les mineurs de charbon du Nord de la France: Étude clinique, problimes diagnostiques et thérapeutiques á propos de 59 observations. Lille méd., 3 ser., 6, 551 .

Gilchrist, R. K. (1940). Fundamental factors governing lymphatic spread of carcinoma. Ann. Surg., 111, 630.

Heppleston, A. G. (1947). The essential lesion of pneumokoniosis in Welsh coal workers. J. Path. Bact., 59, 453.

International Labour Office (1959). Meeting of experts on the international classification of radiographs of the pneumoconioses. Occup. Safety Hlth, 9, 63.

McKerrow, C. B., McDermott, M., and Gilson, J. C. (1960) A spirometer for measuring the forced expiratory volume with a simple calibrating device. Lancet, 1,149 .

Pryce, D. M., and Walter, J. B. (1960). The frequency of gross vascular invasion in lung cancer with special reference to arterial invasion. J. Path. Bact., 79, 141.

Smith, R. Abbey (1959). Lung cancer in coal-miners. Brit. J. industr. Med., 16, 318.

Willis, R. A. (1952). In The Spread of Tumours in the Human Body, 2nd ed., p. 23. Butterworth, London.

Zeidman, I., and Buss, J. M. (1954). Experimental studies on the spread of cancer in the lymphatic system. 1. Effectiveness of the lymph node as a barrier to the passage of embolic tumor cells. Cancer Res., 14, 403.

\section{APPENDIX}

SIGNIFICANCE OF SURVIVAL RATES OF MINERS AND NON-MINERS TREATED SURGICALLY

The significance of the difference between the survival rates of miners and non-miners treated surgically, as expressed in Table IV, was tested by taking a confidence limit of the survival curve of each group based on the square root of the number of deaths observed for estimating the percentage survival at each time interval between six months and five years. The combined confidence limits of the two curves have an approximate $P$ value of $0 \cdot 05$. By this method it is estimated that the differences in survival rates between miners and non-miners from six months to five years after surgical resection are not statistically significant. 